\title{
Effect of two pre-freezing methods on quality of sexed semen in Ettawa Grade goat
}

\author{
Y.S. Ondho ${ }^{1, *}$ and S.B. Udrayana ${ }^{2}$ \\ ${ }^{1}$ Faculty of Animal and Agricultural Sciences, Diponegoro University, \\ Tembalang Campus, Semarang 50275 - Indonesia \\ ${ }^{2}$ Agriculture Extension College, Jl. Dr. Cipto No.144a, Sengkkrajan, Bedali, Lawang, \\ Malang, East Java 65215 - Indonesia \\ *CorrespondingE-mail: yon_supriondho@yahoo.com
}

Received September 14, 2018; Accepted November 13, 2018

\begin{abstract}
ABSTRAK
Tujuan penelitian ini adalah untuk mengetahui pengaruh perbedaan prosedur pra-pembekuan terhadap kualitas sperma hasil pemisahan kromosom X dan Y (sperma sexing) pada kambing Peranakan Ettawa. Materi penelitian berupa semen yang telah dilakukan sexing yang terdiri dari 2 lapisan (lapis atas dan lapis bawah). Semen hasil sexing tersebut diberi dua perlakuan, 1) sesuai dengan standar operating prosedur (SOP) pabrik semen beku, yaitu pre-freezing dengan menempatkan straw $4 \mathrm{~cm}$ di atas $\mathrm{N}_{2}$ cair selama 9 menit, dan 2) perlakuan modifikasi atau prosedur modifikasi (PM), yaitu prefreezing dengan menempatkan straw $16 \mathrm{~cm}$ di atas nitrogen cair selama 9 menit kemudian diturunkan menjadi $4 \mathrm{~cm}$ di atas nitrogen cair selama 9 menit. Parameter yang diamati adalah motilitas, motilitas progresif (gerakan maju), hiperaktivitas dan linieritas sperma. Data yang diperoleh dianalisis dengan menggunakan Student's t-test Hasil penelitian menunjukkan bahwa kualitas semen sexing pada SOP pabrik dibandingkan dengan perlakuan modifikasi terhadap lapisan atas dan bawah masing-masing adalah: motilitas pada lapisan atas (46.06 $\pm 7.52 \%$ vs $55.6 \pm 7.78 \%)$ dan lapisan bawah $(36.82 \pm 6.49 \%$ vs $41.47 \pm 6.57 \%$; progresif pada lapisan atas $(16.34 \pm 4.27$ vs $32.83 \pm 5.9 \%)$ dan lapisan bawah 15.97 $\pm 2.72 \%$ vs $19.79 \pm 3.97 \%)$; hiperaktivitas pada lapisan atas $(0.81 \pm 0.6 \%$ vs $4.09 \pm 1.98 \%)$ dan lapisan bawah $(0.71 \pm 0.68 \%$ vs $1.50 \pm 1.05 \%)$; linieritas pada lapisan atas $(12.19 \pm 2.94$ vs $20.52 \pm 3.97 \%)$ dan pada lapisan bawah $12.32 \pm 2.63$ vs $14.70 \pm 2.6$; non linier pada lapisan atas $(0.14 \pm 0.2$ vs $0.68 \pm$ $0.85 \%)$ dan lapisan bawah $(0.4 \pm 0.13 \%$ vs $0.34 \pm 0.4 \%)$. Simpulan penelitian ini adalah kualitas semen beku sexing yang diproses dengan teknik modifikasi lebih baik dibandingkan dengan semen beku yang diproses dengan operating prosedur pabrik semen beku.
\end{abstract}

Kata kunci: spermatozoa beku, pre-freezing, peranakan kambing Ettawa

\section{ABSTRACT}

The aim of this study was to determine the influence of pre-freezing different procedures to the quality of Ettawa Grade goat frozen semen-sexing. The research material was semen sexing consisted of 2 layers those were top layer and bottom layer. The quality of frozen semen sexing was observed by comparing the pre-freezing technique (factory standard operating procedure: FSOP) according to the Artificial Insemination Center operating procedure (pre-freezing by placing the straw of semen for about $4 \mathrm{~cm}$ above liquid nitrogen for 9 minutes) with the modification procedure (MP), pre-freezing by placing the straw of semen $16 \mathrm{~cm}$ above liquid nitrogen for 9 minutes and then it was lowered to $4 \mathrm{~cm}$ above liquid nitrogen for 9 minutes during the pre-freezing phase. The parameters observed were motility, progressive motility, hyperactivation, and sperm linearity. Data were analyzed using Student's t-test. The 
results of this study indicated that the quality of sexed-semen in the standard operating procedures of frozen semen compared to the treatment of modifications to the top and bottom layers were motility at the top layer ( $46.06 \pm 7.52 \%$ vs $55.6 \pm 7.78 \%)$ and bottom layer (36.82 $\pm 6.49 \%$ vs. $41.47 \pm 6.57 \%$ ); progressive top layer $(16.34 \pm 4.27$ vs. $32.83 \pm 5.9 \%)$ and bottom layer $15.97 \pm 2.72 \%$ vs. $19.79 \pm$ $3.97 \%)$; hyperactivity in the top layer $(0.81 \pm 0.6 \%$ vs $4.09 \pm 1.98 \%)$ and the bottom layer $(0.71 \pm$ $0.68 \%$ vs. $1.50 \pm 1.05 \%)$; linearity consisted of linear and non-linear, the top layer $(12.19 \pm 2.94$ vs. $20.52 \pm 3.97 \%)$ and bottom layer $(12.32 \pm 2.63$ vs $14.70 \pm 2.6)$; while non-linear in top layer $(0.14 \pm 0.2$ vs $0.68 \pm 0.85 \%)$ and bottom layer $(0.4 \pm 0.13 \%$ vs $0.34 \pm 0.4 \%)$. The conclusions in this study indicated that the quality of the frozen sexed-semen that has processed by pre-freezing modification technique was better than the frozen sexed-semen obtained from the Artificial Insemination Center Standard Operating procedure.

Keywords: frozen semen, pre-freezing, Ettawa grade goat

\section{INTRODUCTION}

Semen sexing procedure is attractive and prospective, because it can be used to select sex animal livestock as needed. Semen sexing sperm contribute a great impact on breeding programs, but it needs high cost and resulted in low pregnancy rate especially for artificial insemination (Carvalho et al., 2010; Tubman et al., 2004). One of the factors that affected to the semen quality is frozen semen production system (Seidel, 2009; Moce and Vicente, 2002; Foote, 1990). The results of various studies on sexing methods and materials have been directed at humans and certain animal species, such as dairy cows and beef cattle. The $\mathrm{X}$ and $\mathrm{Y}$ sperm were sexed based on the characteristics that are possessed by each type of sperm, including the DNA content, size, motility, surface charge and chromosome fluorescence. The chromatin content of $\mathrm{X}$ sperm is greater, making the head size is greater than Y sperm (Hafez and Hafez, 2000); in addition, $\mathrm{X}$ sperm contain $3.8 \%$ more DNA than Y sperm (Garner and Seidel, 2000).

In previous studies, the quality of frozen semen sexing after thawing always decreased mainly on the quality after thawing included forward movement, activation and quality degradation (Acker and Gann, 2003). This was a problem because the semen sexing inseminated on the female animal will result in lower percentage of conception. Cochran et al. (1985) stated that pre-freezing and thawing are factors that can affect to a decrease in the quality of semen in ram. The decrease in the quality of the semen is due to the influence of physical and chemical effects on sperm cells when it was separated to obtain the proportion of sperm X or sperm Y. Sperm motility is determined by the availability of energy obtained from the Adenosine Triphosphate (ATP), in addition to the plasma concentration of semen (Hafez and Hafez, 2000). Process of pre-freezing semen by the manufacturers generally only one stage after the equilibration process. This is due to obtain efficiency in the time process and cost production.

Various methods have been developed to obtain optimal results, included the use of different technique, equipment, and the addition of various substances (medium) that can protect or damage the spermatozoa (Yamashiro et al. 2006). The sexing and freezing of sperm can cause damage and lead to death. Therefore, a study investigated the modification of freezing semen for sexing using Bovine Serum Albumine (BSA) gradient centrifugation particularly during the pre-freezing stage (Tartaglione and Ritta, 2004). Correa et al. (1997) stated that semen mortality and occurrence of sperm cell abnormalities during this freezing resulted from the pre-freezing stage of time being too rapid to deep the semen into liquid $\mathrm{N}_{2}$, so that with longer pre-freezing time stages, sperm cells have a sufficient chance to adapt to their ambient temperature well. Susilowati (2017) showed that the best distance of straw from liquid nitrogen surface is $8-10 \mathrm{~cm}$. The method can improve the quality of semen sexing after being frozen, there is no procedure has been reported for sexing frozen semen. On the basis of the reason above, this study was conducted to determine differences of pre-freezing procedure that influence the quality of goat sexed semen.

\section{MATERIALS AND METHODS}

\section{Semen Sexing Preparation}

This research was conducted at the Artificial Insemination Center (AIC) of SidomulyoUngaran, Central Java. Fresh semen was collected 
from 5 PE goats and microscopically evaluated for quality (Table 1). Furthermore, the fresh semen was added with $10 \%$ phosphatidylcholine and examined its quality (Table 2), then the sexing process was carried out. The sexing procedure used a centrifugation technique in which fresh semen has been added with $10 \%$ phosphatidylcholine in $10 \%$ gradient of Bovine Serum Albumine (BSA) and then centrifuged in AndroMed media at a speed of $1500 \mathrm{rpm}$ for 5 minutes (Hamano, 2007). After the centrifugation (post sexing), two layers of top layer post sexing (TLPS) and bottom layer post sexing (BLPS) 10\% gradient of BSA were centrifuged in AndroMed media at a speed of $1500 \mathrm{rpm}$ for 5 minutes (Hamano, 2007).

BSA diluter is capable of separating sperm cells based on their size and weight differences, so that when centrifugation occurs two layers appear in the centrifugation tube. The formation of the upper and lower layers due to differences in the concentration of sperm X and Y. Spermatozoa $Y$ is concentrated in the lower layer, because of the occurrence of centrifugal force, the material that has a bigger size and weight (sperm Y) will reach the base of the tube faster (bottom layer). The upper and lower layers of semenn were then separated and each was inserted into the erlenmeyer and then equilibrated at a temperature of $50^{\circ} \mathrm{C}$. Then the sexing semen (top and bottom layers) was inserted into the mini-straw and prefreezing

\section{Treatments}

There were 2 treatments: 1) pre-freezing by placing the straw of semen at $4 \mathrm{~cm}$ above liquid nitrogen for 9 minutes (factory standard operating procedure or FSOP), and 2) pre-freezing by placing the straw of semen at $16 \mathrm{~cm}$ above liquid nitrogen for 9 minutes and then placing it into 4 $\mathrm{cm}$ above liquid nitrogen for 9 minutes (modification procedure; MP).

\section{Data Analysis}

The quality of the frozen semen sexing (motility, progressive motility, linearity) and postfreezing semen to measure motility, progressive motility, hyperactivity of the sperm and linearity were measured using Computer-Assisted Sperm Analysis (CASA). Replication were performed 7 times a day for one day. Data were analyzed using Student's t-test (Steel and Torrie, 1991).

\section{RESULT AND DISCUSSION}

\section{Quality of Fresh Semen of Ettawa Buck Added with $10 \%$ Phosphatidylcholine}

The fresh semen quality of Ettawa Grade in this research was shown in Table 1 . The quality of the semen is eligible for frozen semen-sexing production (Toelihere, 1993). Before sexing process, fresh semen was added with $10 \%$ phosphatidylcholine so that the quality remains good. Mean motility, progression and linearity of fresh semen after adding $10 \%$ phosphatidylcholine was $80 \%$ to $90 \%, 75 \%$ to $80 \%$ and $45 \%$ to $55 \%$, respectively. The quality improvement after addition of diluent is conducted to improve the metabolite functions of organelles in spermatozoa cells utilizing the nutrients provide from the diluents (Hammadeh et al., 2001). In addition, phosphatidylcholine serves

Table 1. Microscopic Evaluation of Motility, Progressive and Linearity on Fresh Semen Ettawa Grade Goat

\begin{tabular}{|c|c|c|c|}
\hline \multirow{2}{*}{ Buck } & \multicolumn{3}{|c|}{ Parameters } \\
\hline & Motility & Progressive & Linearity \\
\hline & \multicolumn{3}{|c|}{ (1) \% } \\
\hline 1 & 80 & 75 & 45 \\
\hline 2 & 85 & 80 & 50 \\
\hline 3 & 80 & 75 & 45 \\
\hline 4 & 80 & 70 & 40 \\
\hline 5 & 75 & 75 & 45 \\
\hline Average & 80 & 75 & 45 \\
\hline
\end{tabular}


as a buffer increasing the volume of semen and providing energy. Phosphatidylcholine increased activity of sperm cell membrane metabolism and caused motility. Another benefit of phosphatidylcholine in the diluent can protect sperm cells from mechanical damage such as reducing cellular damage due to freezing or centrifugation effect. Pesch and Hoffmann (2007), Nabiev (2003) and Park and Graham (1992) stated that addition with $10 \%$ phosphatidylcholine in the AndroMed diluent would improve hyperactiveness and linearity of sperm. Phosphatidylcholine protects the sperm membrane and triggers the activity of enzymes located in the spermatozoa acrosome. Nehring and Rothe (2003) and Aires et al. (2003) stated that the increasing number of linearity sperm affect directly to the increase in sperm hyperactivity with the strength of cell membranes and the occurrence of acrosome reactions, and the increasing of hyperactivity of the cell sperm. The more aggressiveness and linear movement can be observed by microscopic observations. Correa et al. (1997) reported that progressive movements of the sperm head are supported by movement of the tail of spermatozoa. The progressive movement are the combination between hyperactivity movement and linearity.

\section{Quality of Post-sexing Semen}

Centrifugation process during semen sexing resulted on 2 layer (top and bottom layer). Semen sexing process affected to the decreasing of semen quality. Centrifugation process affected to the physical destruction and resulted in disturbing metabolic activity. In this research, decreasing semen quality did not fell down under standard for frozen semen production. This is because spermatozoa cells have been strengthened by adding $\quad 10 \%$ phosphatidylcholine before processing of semen sexing. Motility, progressive motility and linearity of fresh semen added with $10 \%$ phosphatidylcholine (FS + PPC) and post sexing (Top Layer Post Sexing (TLPS) and Bottom Layer Post Sexing (BLPS) on Ettawa Grade goat was shown in Table 2.

\section{Pre-freezing Semen Quality}

The semen quality of pre-freezing on factory standard operating procedure (FSOP) compared with modification procedures (MP) is presented in Table 3. Based on this result, the technique of prefreezing modification in freezing process of semen sexing can increase motility and linier movement of spermatozoa cell $(\mathrm{P}<0.05)$, similarly sperm progressive motility and hyperactive compared with standard procedures $(\mathrm{P}<0.01)$. Table 3 shows that in the top layer, the modified treatment of almost all variables showed better results compared to the factory standard procedure, only parameter non-linear movement that shown non significant difference $(\mathrm{P}>0,05)$. In the bottom layer, although statistical analysis of some variables did not show significant differences, but there was a tendency that prefreezing modification treatments improved semen

Table 2. Microscopic Evaluation of Motility, Progressive and Linearity on Fresh Semen (FS) Added with 10\% Phosphatidylcholine (FS+PPC) and Post Sexing (Top Layer Post Sexing/TLPS, Bottom Layer Post Sexing/BLPS) on Ettawa Grade Goat

\begin{tabular}{|c|c|c|c|c|c|c|c|c|c|}
\hline \multirow{2}{*}{ Buck } & \multicolumn{3}{|c|}{ Motility } & \multicolumn{3}{|c|}{ Progressive } & \multicolumn{3}{|c|}{ Liniarity } \\
\hline & $\mathrm{FS}+\mathrm{PPC}$ & TLPS & BLPS & $\mathrm{FS}+\mathrm{PPC}$ & TLPS & BLPS & $\mathrm{FS}+\mathrm{PPC}$ & TLPS & BLPS \\
\hline & & & & &..$\%$ & …….... & …… & $\ldots \ldots \ldots$ & ............ \\
\hline 1 & 90 & 85 & 80 & 80 & 75 & 85 & 55 & 45 & 60 \\
\hline 2 & 95 & 90 & 85 & 85 & 70 & 80 & 60 & 55 & 50 \\
\hline 3 & 90 & 85 & 80 & 80 & 70 & 75 & 55 & 50 & 55 \\
\hline 4 & 90 & 80 & 80 & 75 & 65 & 75 & 50 & 45 & 50 \\
\hline 5 & 85 & 85 & 75 & 80 & 70 & 85 & 55 & 50 & 50 \\
\hline Average & 90 & 85 & 85 & 80 & 70 & 80 & 55 & 50 & 55 \\
\hline
\end{tabular}


Table 3. Average Value of Variables Different Pre-freezing on Factory Standard Operating Procedure (FSOP) and Modification Procedures (MP) Treatment

\begin{tabular}{lccccc}
\multirow{2}{*}{ Variables } & \multicolumn{2}{c}{ Top Layer } & & \multicolumn{2}{c}{ Bottom Layer } \\
\cline { 2 - 3 } Motility & FSOP & MP & & FSOP & MP \\
Progressive & $46.06 \pm 7.52^{\mathrm{a}}$ & $55.61 \pm 7.78^{\mathrm{b}}$ & & $36.82 \pm 6.49^{\mathrm{a}}$ & $41.47 \pm 6.57^{\mathrm{a}}$ \\
Linearity & $16.34 \pm 4.27^{\mathrm{a}}$ & $32.83 \pm 5.91^{\mathrm{b}}$ & & $15.97 \pm 2.72^{\mathrm{a}}$ & $19.79 \pm 3.97^{\mathrm{b}}$ \\
Hyperactive & $12.19 \pm 2.94^{\mathrm{a}}$ & $20.52 \pm 3.97^{\mathrm{b}}$ & & $12.32 \pm 2.63$ & $14.70 \pm 2.63$ \\
Non Linear & $0.81 \pm 0.60^{\mathrm{a}}$ & $4.09 \pm 1.98^{\mathrm{b}}$ & & $0.71 \pm 0.68^{\mathrm{a}}$ & $1.50 \pm 1.05^{\mathrm{b}}$ \\
\hline
\end{tabular}

Different superscript in the same row at a trait indicate a significantly different $(\mathrm{P}<0.05)$. FSOP: Factory Standard Operational Procedure; MP: Modification Procedure

quality, in this case only motility variables was significantly different $(\mathrm{P}<0.01)$. According to Carvalho et al. (2010) the semen sexing procedure affected sperm characteristics, it did not significantly affect fertilization or embryo development.

Table 3 shows that the quality of sperm increased significantly with the modified treatment in pre-freezing. It is known that the process of sperm freezing can damage spermatozoa cells, so that modification technique was required to reduce the damage of spermatozoa cells. The treatment of modification pre-freezing was done by placing the straw of semen $16 \mathrm{~cm}$ above liquid nitrogen for 9 minutes that was intended to gradually lower the freezing temperature with a distance of $16 \mathrm{~cm}$ above the surface of liquid nitrogen after have been equilibrated at $3-4^{\circ} \mathrm{C}$ for 4 hours, then the semen was lowered to $4 \mathrm{~cm}$ from the surface of the liquid $\mathrm{N}_{2}$ for 9 minutes. After that, it was frozen by decreasing the temperature of about $-30^{\circ} \mathrm{C}$ then $-130^{\circ} \mathrm{C}$, and finally semen (already inside the packing straw) was soaked in liquid $\mathrm{N}_{2}$. This modification technique has a positive effect on the quality of semen that is suitable to be used for insemination as stated by Toelihere (1993). Table 3 shows significant degradation of the semen quality when semen was aligned followed by freezing process. Freezing process used as modified procedure has produced better quality semen than using standard factory procedure. This result was the same as the statement of Correa et al. (1997) that modification in freezing process of semen sexing can increase the semen quality. Thus, the modification procedure in this study may increase the percentage of motility, included forward movement, hyperactive, linear and nonlinear movements in both top and bottom layers of semen sexing. It is noted that the quality of semen after processing (frozen or sexing) decreased about $15-20 \%$ compared to fresh semen, although it can still be used for insemination. Based on this study, the modification of procedures can improve the quality of semen on 5 variables as observed and measured by using Computer-Assisted Sperm Analysis (CASA). Furthermore, the production of frozen semen sexing by modification of the prefreezing procedure needs a field-test to be able to obtain pregnancy data resulting from insemination by using the frozen semen sexing.

\section{CONCLUSION}

Modification Procedure (MP) at the prefreezing stage of semen for sexing could increase the motility, progression, hyperactivity and linearity of the sperm top layers. Modification Procedure (MP) of pre-freezing increased progressive sperm in the bottom layers. Modification of pre-freezing semen for sexing with a two-stage pre-freezing procedure produced better-quality sperm than did the factory standard operating procedure (FSOP).

\section{REFERENCES}

Acker, J.P. and L.E. Mc Gann. 2003. Protective effect of intracellular ice during freezing. Cryobiology. 46: 197-202.

Aires, V.A., K.D. Hinsch, F.M. Schloesser, K. 
Bogner, S.M. Schloesser and E. Hinsch. 2003. In vitro and in vivo comparison of egg yolk based and soybean lechitin based extenders for cryopreservation of bovine semen. Theriogenology. 60: 269-279.

Carvalho, J.O., R.Sartori, G.M. Machado, G.B. Mourao and M.A.N. Dode. 2010. Quality assessment of bovine cryopreserved sperm after sexing by flow cytometri and their use in in vitro embryo production. Theriogenology. 74:1521-1530

Correa, J.R. G. Heersche, Jr. and P.M. Zavos. 1997. Sperm membrane functional integrity and response of frozen-thawed bovine spermatozoa during hypoosmotic swelling test incubation at varying temperatures. Theriogenology. 47:715-721.

Foote, R.H. 1990. Cryopreservation of spermatozoa and artificial insemination: past present and future. J. Androl. 3: 85-100.

Cochran, R.C., J.K. Judi, J.F. Parker and D.M. Hallford. 1993. Prefreezing and post-thaw semen characteristics of five ram breeds collected by electroejaculation. Theriogenology. 23:431-434.

Garrner, D.L. and E.S.E Hafez. 2000. Spermatozoa and Seminal Plasma. In: Reproduction in Farm Animal. $7^{\text {th }}$ Ed. Edited by B. Hafez and E.S.E. Hafez. Lippincott Williams \& Wilkins. Philadelphia.

Garner, D.L. and G.E. Seidel. 2000. Sexing Bull Sperm. In: Topics in Bull Fertility. Edited by P.J. Chenoweth. International Veterinary Information Service.

Hafez, E.S.E. and B. Hafez. 2000. X and Y Chromosome Bearing Spermatozoa. In: Reproduction in Farm Animals. $7^{\text {th }}$ Ed. Edited by B. Hafez and E.S.E. Hafez. Lippincott Williams \& Wilkins. Philadelphia.

Hamano, K.2007. Sex preselection in bovine by separation of $\mathrm{X}$ and $\mathrm{Y}$ chromosome bearing spermatozoa. J. Reprod. Dev. 53(1):27-38.

Hammadeh, M.E., T.George, P.Rosenbaum and W. Schmidt. 2001. Assosiation between freezing agent and acrosome damage of human spermatozoa from sub normal and normal sperm. Andrologia 32:331-336.

Hans, B. And J.C. Bischof, 2004. Direct cell injury associated with eutethic crystalization during freezing. Cryobiology. 48:8-21.

Matsuoka, T., H. Imai, H. Kohno and Y. Fukui. 2006. Effects of bovine serum albumin and trehalosa in semen diluents for improvement of frozen thawed ram spermatozoa. J. Reprod. and Dev. 52(5): 675-683.

Moce, E. and J.S. Vicente. 2002. Effect of cooling and freezing, the two steps of a freezing protocol on fertilizing ability of rabbit sperm. Reprod. Nut. Dev. 42:189-196.

Nabiev, D., M. Giles, H. Scheider, E. Mahibir, K. Wimmers, A. Ponsuksili, H. Koll and K. Schellander. 2003. Comparison of andromed and tris egg yolk extender bovine post thaw sperm function parameters and IVF. Theriogenology. 38:209-222.

Nehring, H. And L. Rothe. 2003. Insemination of cryopreserved bull semen portions with reduced sperm number after freezing and thawing is related to cellular injury. Biol. Reprod. 71:973-978.

Park, J.E., and J.K. Graham. 1992.Effects of cryopreservation procedures on sperm membranes. Theriogenology. 38: 209-222.

Pesch, S. and B. Hoffmann. 2007. Cryopreservation of spermatozoa in veterinary medicine. J. Reprod. Endoc. 4: 101-105.

Seidel, Jr. G.E. 2009. Sperm sexing techcnology. The transition to commercial application. An Introduction to the symposium "update on sexing mammalian sperm". Theriogenology. 7:1-3

SNI. 2017. Standard Nasional Indonesia Semen Beku 4869-1.2.2017. Semen Beku Bagin 1: Sapi. Badan Standardisasi Nasional. Jakarta.

Susilawati, T. 2017. Spermatology. Cetakan Kedua. Penerbit Universitas Brawijaya Press. Malang-Indonesia

Steel, R.G.D. and J.H. Torrie. 1980. Principles and Procedures of Statistics. A Biometrical Approach. $\quad 2^{\text {nd }} \quad$ Ed. McMgraw-Hill Kogakusha, Ltd.

Tartaglione, C.M. and M.N. Ritta. 2004. Prognostic value of spermatological parameters as predictors of in vitro fertility of frozen-thawed bull semen. Theriogenology. 62:1245-1252.

Toelihere, M.R.1993. Inseminasi Buatan pada Ternak. Penerbit Angkasa Bandung

Tubman, L.M., Z. Brink, T.K. Suh and G.E. Seidel. 2004. Characteristics of Calves Produced with Sperm Sexed by Flow Cytometri/Cell Sorting. In Animal Growth, Physiology and Reproduction. Animal Reproduction and Biotechnology Laboratory. Colorado State University. Fort 
Collins.

Yamashiro, H., H.F. Wang, Y. Yamashita, K. Kumamoto and T. Terada. 2006. Enhanced freezability of goat spermatozoa collected into tubes containing extender supplemented with bovine serum albumin (BSA). J. Reprod. Dev. 52(3):407-414. 